\title{
ПИТАТЕЛЬНАЯ И БИОЛОГИЧЕСКАЯ ПОЛНОЦЕННОСТЬ МЯСА МОЛОДНЯКА ОВЕЦ БУРЯТСКОЙ ГРУБОШЕРСТНОЙ И ТУВИНСКОЙ КОРОТКОЖИРНОХВОСТОЙ ПОРОД
}

\author{
E. C. Dymbrylova, S. I. Biltuev, \\ V. A. Achituev, B. V. Zhamyanov

\section{NUTRITIONAL AND BIOLOGICAL VALUE OF LAMB MEAT OF BURYAT COARSE WOOL AND TUVAN SHORT FAT-TAILED SHEEP BREEDS}

Дымбрылова Эржена Цыренпунсыковна асп. каф. частной зоотехнии и технологии производства продукции животноводства Бурятской государственной сельскохозяйственной академии им. В.Р. Филиппова, г. Улан-Удэ.

E-mail: dymbrylova_erzhena@mail.ru

Билтуев Семен Иннокентьевич - д-р с.-х. наук, проф. каф. частной зоотехнии и технологии производства продукции животноводства Бурятской государственной сельскохозяйственной академии им. В.Р. Филиппова, г. Улан-Удэ.

E-mail: bair1717@mail.ru

Ачитуев Владимир Александрович - канд. с.-х. наук, доц., зав. каф. частной зоотехнии и технологии производства продукции животноводства Бурятской государственной сельскохозяйственной академии им. В.Р. Филиппова, г. Улан-Удэ.

E-mail: achvlad@mail.ru

Жамьянов Баир Валерьевич - канд. с.-х. наук, доц. каф. частной зоотехнии и технологии производства продукции животноводства Бурятской государственной сельскохозяйственной академии им. В.Р. Филиппова, г. Улан-Удэ.

E-mail: bair1717@mail.ru

Цель исследования - изучение питательной и биологической полноценности мяса молодняка бурятской грубошерстной и тувинской короткожирнохвостой пород. Проведен сравнительный анализ между исследуемыми группами. Контрольный убой 3 голов в возрасте 7 месяцев проведен по методике ВИЖа. По результатам исследования отмечено преимущество валушков бурятской грубошерстной породы по массе туши (17,58 ке) на 1,56 ке и убойному выходу (52,74 \%) на 4,38 \% перед молодняком тувинской короткожирнохвостой породы. Согласно анализу данных химического состава сред-
Dymbrylova Erzhena Tsyrenpunsykovna - PostGraduate Student, Chair of Private Zootechnics and Technology of Animal Husbandry Production, Buryat State Agricultural Academy named after V.R. Filippov, Ulan-Ude.

E-mail: dymbrylova_erzhena@mail.ru

Biltuev Semyon Innokentyevich - Dr. Agr. Sci, Prof., Chair of Private Zootechnics and Technology of Animal Husbandry Production, Buryat State Agricultural Academy named after V. R. Filippov, UlanUde.

E-mail: bair1717@mail.ru

Achituev Vladimir Alexandrovich - Cand. Agr. Sci., Assoc. Prof., Head Chair of Private Zootechnics and Technology of Animal Husbandry Production, Buryat State Agricultural Academy named after V.R. Filippov, Ulan-Ude.

E-mail: achvlad@mail.ru

Zhamyanov Bair Valeryevich - Cand. Agr. Sci., Assoc. Prof., Chair of Private Zootechnics and Technology of Animal Husbandry Production, Buryat State Agricultural Academy named after V.R. Filippov, UlanUde.

E-mail: bair1717@mail.ru

ней пробы, в мясе содержалось 18,36 \% белка, и по этому показателю бурятские грубошерстные валушки превосходили тувинских короткожирнохвостых сверстников на 3,78 \%, уступая последним по содержанию в мясе жира на 2,97 \%. По содержанию в мясе влаги и золы различия между животными сравниваемых групп были незначительны. Вместе с тем валушки тувинской короткожирнохвостой породы превосходили бурятских грубошерстных сверстников: по энергетической ценности - на 0,84 мДж; калорийности - на 202,43 ккал, или 10,8 и 10,9 \% соответственно. Мясо и бульон 
молодняка обеих пород имели высокие вкусовые качества с оценкой 8,1 и 8,05 у бурятских грубошерстных валушков, 7,4 и 7,75 - у тувинских короткожирнохвостых сверстников. Также было определено содержание заменимых и незаменимых аминокислот. Содержание тяжелых металлов не превышает предельно допустимую норму и согласуется с исследованиями других авторов. Согласно полученным данным, можно сделать вывод, что мясо молодняка обеих пород соответствует требованиям экологически чистого пищевого продукта.

Ключевые слова: овцы, мясо, мясная продуктивность, влага, белок, жир, зола, аминокислоты, тяжелье металлы, дегустация.

The research objective was studying nutritional and biological value of meat of young growth of Buryat coarse wool and Tuvan short fat-tailed sheep breeds. The comparative analysis between these studied groups was carried out. Control slaughter of 3 heads at the age of 7 months was carried out by L.K. Ernst Institute of Animal Husbandry's technique. $B y$ the results of the research the advantage of the ram of Buryat coarse breed in carcass mass $(17.58 \mathrm{~kg})$ in $1.56 \mathrm{~kg}$ and to lethal exit (52.74 \%) to $4.38 \%$ before young growth of Tuvan short fat-tailed sheep breeds breed was noted. According to the analysis of data of chemical composition of average test, meat contained $18.36 \%$ of protein, and Buryat coarse wool ram surpassed Tuvan short fat-tailed sheep breeds' contemporaries in this indicator by $3.78 \%$, and lagged behind according to the contents of fat in the meat by $2.97 \%$. According to the contents of moisture and ashes in the meat the distinction between the animals of compared groups was insignificant. At the same time the ram of Tuvan short fat-tailed sheep breed surpassed Buryat coarse-wool rams in energy value by $0.84 \mathrm{~mJ}$, in calorific value by $202.43 \mathrm{kcal}$, or $10.8 \%$ and $10.9 \%$. Meat and broth of young growth of both breeds had high tastes with the assessment 8.1 and 8.05 in Buryat coarse wool ram, 7.4 and 7.75 in Tuvan short fat-tailed sheep contemporaries. Also the content of replaceable and irreplaceable amino acids was defined. The content of heavy metals did not exceed maximum permissible norm and was in accordance with the results of other researches. According to the obtained data, it is possible to draw the conclusion that the meat of young growth of both breeds con- forms to the requirements of environmentally friendly foodstuff.

Keywords: sheep, meat, meat efficiency, moisture, protein, fat, ashes, amino acids, heavy metals, tasting.

Введение. Овцеводство является экономически значимой отраслью Республики Бурятия, обеспечивающей население ценным продуктом питания - бараниной, а промышленность шерстяным сырьем. Здесь развитию овцеводства способствует наличие огромных просторов степных и горных пастбищ, а сухой климат позволяет использовать природные пастбища в течение круглого года при минимальных затратах заготовленных кормов [1].

В свете сложившейся ситуации актуальным вопросом является разведение тех пород и типов животных, которые наиболее приспособлены к определенным местным условиям и дают наибольший выход продукции при небольших затратах средств и труда.

Бурят-монгольские грубошерстные породы в свое время находили широкое распространение на территории Забайкальского края, Республики Бурятия и Иркутской области, а также в отдельных регионах Монгольской Народной Республики и Китая. Этим овцам свойственны крепкая конституция, живой и энергичный темперамент, хорошо развит материнский инстинкт, способность быстро восстанавливать зимние потери живой массы в период летне-осеннего нагула на сочных, богатых питательными веществами природных пастбищах [2].

В 2012 г. Буддийская традиционная Сангха России по программе создания «социальной отары» завезла в СПК «Иро» Селенгинского района Республики Бурятия тувинскую короткожирнохвостую породу овец степного типа, созданную коллективом авторов в период 19982010 гг. в хозяйствах южных и центральных кожуунов Республики Тыва [3]. Основной экономически значимой продукцией этих овец, как и бурятских грубошерстных, является дешевое мясо.

Цель исследования: изучение у молодняка овец бурятской грубошерстной и тувинской короткожирнохвостой пород убойных качеств, энергетической и биологической полноценности мяса в сравнительном аспекте. 
Задачи исследования: изучение убойных качеств, химического состава, энергетической ценности, содержания в мясе аминокислот и тяжелых металлов, оценка вкусовых качеств мяса и бульона.

Объекты и методика исследования. Объектом исследования служили валушки бурятской грубошерстной и тувинской короткожирнохвостой пород, которые после отьема от матерей выращивались в одной отаре и выпасались по природным пастбищам и жнивью зерновых культур. После окончания летне-осеннего нагула продолжительностью 90 дней, в возрасте 7 месяцев был проведен контрольный убой по методике ВИЖа по 3 головы с каждой группы овец [4]. Все исследования были проведены в лабораториях Бурятской ГСХА им. В.Р. Филиппова, ЦКП «Прогресс» при Восточно-Сибирском ГУТУ и в Бурятской республиканской научно-производственной ветеринарной лаборатории. При проведении убоя у молодняка овец были определены следующие показатели: предубойная живая масса, масса парной и охлажденной туши, масса внутреннего жира, убойная масса, убойный выход.

Для изучения химического состава были отобраны пробы по ГОСТ Р 51447-99 и изучены с помощью следующих методик: определение массовой доли влаги - ГОСТ Р 51479-99; определение массовой доли белка - ГОСТ 250112017; определение массовой доли жира - ГОСТ 23042-2015; определение массовой доли общей золы - ГОСТ 31727-2012 [5-8].

При рассмотрении биологической полноценности были определены содержание тяжелых металлов и аминокислотный состав. Методами определения служили: мышьяка - ГОСТ 2693086; ртути - ГОСТ 26927-86; кадмия, свинца, цинка - ГОСТ 30178-96. Для определения аминокислотного состава исследования проводились по нормативным документам метода испытания М-04-38-2009 с использованием системы капиллярного электрофореза «Капель» [9].

Для выяснения вкусовых качеств мяса и бульона сравниваемых пород комиссией были проведены 2 дегустации по ГОСТ 9959-91 по 9-балльной шкале. Органолептическую оценку мяса проводят после его тепловой обработки. Одновременно с оценкой вареного мяса определяют качество бульона. Согласно ГОСТ 99592015, тепловую обработку осуществляют следующим образом: мясо массой около 1 кг по- мещают в кастрюлю с холодной водой (соотношение воды и мяса $3: 1$ ), накрывают крышкой, доводят до кипения и варят на слабом огне в течение 1-1,5 ч до температуры в центре куска $75 \pm 5{ }^{\circ} \mathrm{C}$. За 30 мин до окончания варки кладут поваренную соль в количестве 1 \% к массе мяса. После окончания варки мясо извлекают из бульона и охлаждают до $35 \pm 5{ }^{\circ} \mathrm{C}$, затем нарезают на ломтики массой не менее 50 г и направляют на дегустацию. Мясо оценивалось по внешнему виду, аромату, вкусу, консистенции и сочности. Для оценки органолептических показателей бульона его разливают в стеклянные стаканы в количестве не менее $50 \mathrm{~cm}^{3}$ и определяют: внешний вид и цвет, запах (аромат), вкус и наваристость.

Цифровой материал обработан методом вариационной статистики (Н.А. Плохинский, 1969) с использованием компьютерной программы Excel.

Результаты исследования. В проведенных исследованиях молодняк бурятской грубошерстной в возрасте 7 месяцев имел массу туши 18,48 кг и убойный выход 52,74 \% и по этим показателям превосходил тувинских короткожирнохвостых сверстников на 1,58 и 4,38 \% (табл. 1).

Лучшие убойные качества у молодняка овец бурятской грубошерстной породы, по-видимому, объясняются их более высокой мясной скороспелостью в сравнении с тувинскими короткожирнохвостыми сверстниками.

Похожие результаты по убойным качествам молодняка сравниваемых пород приводят и ряд других авторов, исследовавших убойные качества [3, 10-12]. Разница по массе парной туши молодняка овец бурятской грубошерстной породы в пользу полученных данных составляет 2,18 кг, или 1,13\%. Различия в убойных качествах молодняка овец тувинской короткожирнохвостой пород авторы объясняют природно-кормовыми условиями зоны их выращивания. В Центральностепной зоне при убое молодняка в возрасте 8 месяцев предубойная живая масса составила 38,8 кг, масса парных туш и внутреннего жира 18,3 и 1,2 кг, убойный выход - 50,5 \%, а в опустыненно-степной зоне - соответственно 35,2; 16,3; 1,0 кг и 49,1\%, в горно-степной зоне - 30,6; 13,4; 0,5 кг и 45,1\% [3, 10, 12].

Пищевая и биологическая ценность баранины в основном обуславливается химическим составом мяса (табл. 2). 
Убойные качества молодняка овец разных пород

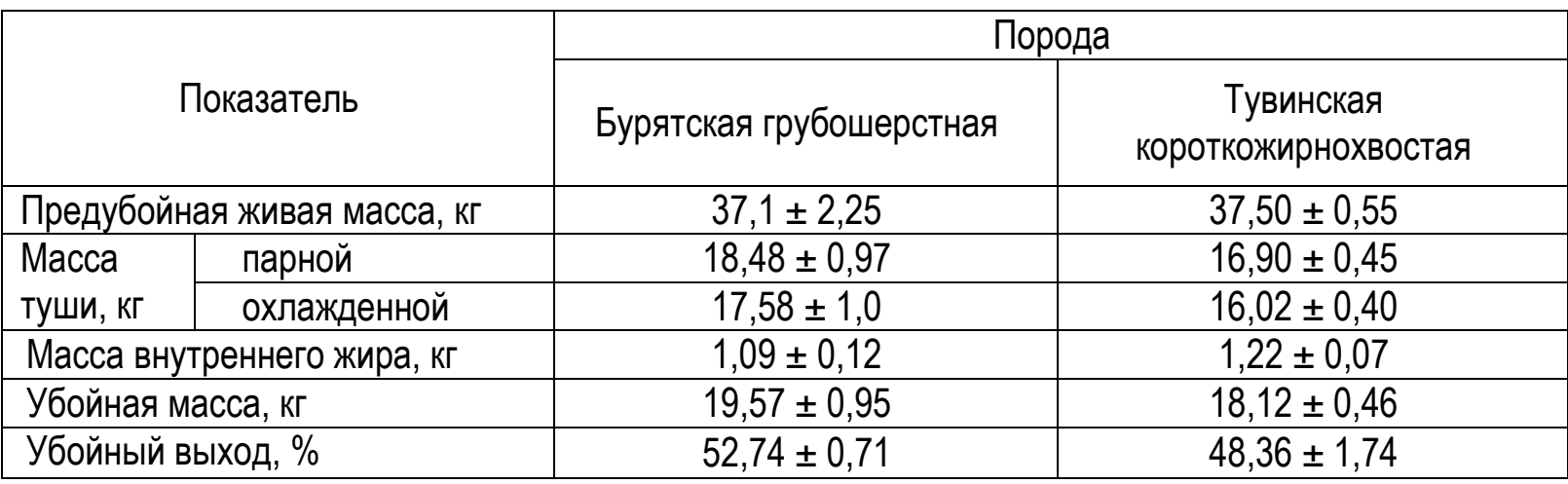

Таблица 2

Химический состав и энергетическая ценность мяса

\begin{tabular}{|c|c|c|}
\hline \multirow[b]{2}{*}{ Показатель } & \multicolumn{2}{|c|}{ Группа } \\
\hline & $\begin{array}{c}\text { Бурятская } \\
\text { грубошерстная }\end{array}$ & $\begin{array}{c}\text { Тувинская } \\
\text { короткожирнохвостая }\end{array}$ \\
\hline \multicolumn{3}{|l|}{ Массовая доля, \%: } \\
\hline влаги & 68,63 & 69,54 \\
\hline белка & 18,36 & 14,58 \\
\hline жира & 11,81 & 14,78 \\
\hline золы & 1,2 & 1,1 \\
\hline Отношение жир/белок & $1: 1,5$ & $1: 0,98$ \\
\hline Калорийность, ккал/100 г & 179,73 & 191,34 \\
\hline Энергетическая ценность, мдж/100 г & 0,75 & 0,80 \\
\hline
\end{tabular}

Анализ данных химического состава средней пробы мяса свидетельствует об определенных различиях между породами. В мясе валушков бурятской грубошерстной породы содержалось 18,36 \% белка и поэтому показателю превосходили тувинских короткожирнохвостых сверстников на $3,78 \%$, уступая последним по содержанию в мясе жира на 2,97\%. По содержанию в мясе влаги и золы различия между животными сравниваемых групп были незначительны. Большее содержание жира в мясе обуславливает высокую его энергетическую ценность. Валушки тувинской короткожирнохвостой породы превосходили бурятских грубошерстных сверстников по энергетической ценности на 0,05 мДж, калорийности - на 11,61 ккал, или 10,6 \%. По данным Ж.Н. Монгуш, энергетическая ценность мяса валушков тувинской короткожирнохвостой породы в возрасте 8 месяцев в зависимости от их линейной принадлежности колебалась в сходных пределах [12, 13].

Некоторые аминокислоты (например глицин, глутаминовая кислота, аланин, треонин, лизин, лейцин и другие) являются важными предшественниками аромата и вкуса мяса. Они при термической обработке подвергаются различного рода реакциям, обуславливающим вкус и аромат мясных продуктов.

В проведенных исследованиях белок мышечной ткани содержит как незаменимые аминокислоты (валин, лейцин + изолейцин, лизин, метионин, треонин, триптофран, фенилаланин), так и заменимые (аланин, аргинин, гистидин, глутаминовая кислота + глутамин, аспаргиновая кислота + аспарагин, пролин, серин, тирозин, глицин), что делает мясо овец биологически полноценным пищевым продуктом (табл. 3). 
Аминокислотный состав мяса, \%/100 мг

\begin{tabular}{|l|c|c|}
\hline \multirow{2}{*}{ Показатель, \%/100 мг } & \multicolumn{2}{|c|}{ Группа } \\
\cline { 2 - 3 } & $\begin{array}{c}\text { Бурятская } \\
\text { грубошерстная }\end{array}$ & $\begin{array}{c}\text { Тувинская } \\
\text { короткожирнохвостая }\end{array}$ \\
\hline Валин & 2,33 & 2,02 \\
\hline Лейцин + изолейцин & 10,47 & 9,22 \\
\hline Лизин & 1,54 & 1,62 \\
\hline Метионин & 0,52 & 0,70 \\
\hline Треонин & 2,34 & 2,46 \\
\hline Триптофан & 0,31 & 0,32 \\
\hline Фенилаланин & 2,18 & 2,02 \\
\hline Аланин & 1,11 & 1,44 \\
\hline Аргинин & 1,73 & 2,04 \\
\hline Гистидин & 2,19 & 2,06 \\
\hline Глутаминовая кислота + глутамин & 5,21 & 6,51 \\
\hline Аспаргиновая кислота + аспарагин & 3,85 & 5,36 \\
\hline Пролин & 2,02 & 1,89 \\
\hline Серин & 3,05 & 3,41 \\
\hline Тирозин & 2,03 & 1,83 \\
\hline Глицин & 4,14 & 4,70 \\
\hline
\end{tabular}

Полученные данные свидетельствуют о том, что в мясе небольшое преимущество по содержанию: валина $(0,31)$; лейцина + изолейцин $(1,25)$; фенилаланина $(0,16)$; гистидина $(0,13)$; пролина $(0,13)$; тирозина $(0,2),-$ отмечено у бурятских грубошерстных валушков, которые уступают сверстникам тувинской короткожирнохвостой породы по содержанию: метионина $(0,18)$; треонина $(0,12)$; аланина $(0,33)$; аргинина $(0,31)$; глутаминовой кислоты + глутамин $(1,3)$; аспаргиновой кислоты + аспарагин $(1,51)$; серина $(0,36)$; глицина $(0,56)$.
Как известно, одним из критериев биологической полноценности мяса является количественное соотношение и наличие в нем тяжелых металлов и микроэлементов. В процессе исследования обнаружено наличие микроэлементов, таких как: кадмий, мышьяк, ртуть, свинец и цинк. Химические элементы, которые относятся к потенциально опасным веществам для человека (свинец, ртуть, мышьяк и кадмии), обнаружены в очень малых количествах (табл. 4) [14-16].

\section{Содержание тяжелых металлов}

\begin{tabular}{|c|c|c|c|}
\hline \multirow[b]{2}{*}{ Показатель, мг/кг } & \multicolumn{2}{|c|}{ Группа } & \multirow{2}{*}{$\begin{array}{c}\text { Предельно } \\
\text { допустимая норма }\end{array}$} \\
\hline & $\begin{array}{c}\text { Бурятская } \\
\text { грубошерстная }\end{array}$ & $\begin{array}{c}\text { Тувинская } \\
\text { короткожирнохвостая }\end{array}$ & \\
\hline Кадмий & $<0,01$ & $<0,01$ & 0,05 \\
\hline Мышьяк & $<0,01$ & $<0,01$ & 0,1 \\
\hline Ртуть & $<0,003$ & $<, 003$ & 0,03 \\
\hline Свинец & 0,20 & 0,19 & 0,5 \\
\hline Цинк & 15,8 & 16,0 & 70,0 \\
\hline
\end{tabular}

Таким образом, в результате проведенного исследования было сделано заключение о том, что наличие установленных микроэлементов в мышечной ткани исследуемых групп молодняка 
овец соответствует требованиям безопасности, так как наличие опасных веществ не достигает предельно допустимой нормы. В то же время имеются небольшие различия между исследуемыми группами. Так, у валушков бурятской грубошерстной содержалось свинца 0,20 мг/кг, что больше на 0,01 мг/кг, но при этом по содержанию цинка преобладают валушки тувинской короткожирнохвостой породы на 0,2 мг/кг. Полу- ченные данные согласуются с исследованиями других авторов [17]. Можно сказать, что полученная баранина является безопасным пищевым продуктом, так как загрязняющие фракторы присутствуют в наименьшей степени.

Дегустационной комиссией были оценены вкусовые качества мяса и бульона сравниваемых пород (табл. 5).

Результаты дегустации

\begin{tabular}{|l|c|c|}
\hline \multirow{2}{*}{ Показатель } & \multicolumn{2}{|c|}{ Порода } \\
\cline { 2 - 3 } & Бурятская грубошерстная & Тувинская коротко-жирнохвостая \\
\hline \multicolumn{3}{|c|}{ Показатели качества мяса } \\
\hline Внешний вид & 8,4 & 8,3 \\
\hline Запах, аромат & 8,2 & 7,8 \\
\hline Вкус & 8,0 & 7,5 \\
\hline Консистенция & 8,9 & 6,6 \\
\hline Сочность & 7,7 & 7,0 \\
\hline Общая оценка & 8,1 & 7,4 \\
\hline & Показатели качества бульона \\
\hline Внешний вид & 8,4 & 7,7 \\
\hline Запах, аромат & 8,2 & 7,7 \\
\hline Вкус & 7,8 & 7,8 \\
\hline Наваристость & 7,8 & 7,8 \\
\hline Общая оценка & 8,05 & 7,75 \\
\hline
\end{tabular}

Анализируя данные таблицы 5, можно сказать, что у валушков бурятской грубошерстной породы лучшие показатели качества мяса: вкус, консистенция, сочность, - на 0,5; 2,3; 0,7 баллов соответственно. Также по показателям качества бульона предпочтение отдано бурятским грубошерстным валушкам. По мнению экспертной комиссии, наиболее лучшими показателями обладали мясо и бульон буряткой грубошерстной породы на 0,7 и 0,3 балла соответственно. Образцы мяса баранины исследуемых пород обладают сочной, нежной консистенцией и имеют небольшой специфический привкус, присущий данному виду мяса.

Таблица 5 
с более высоким содержанием жира, чем у бурятской грубошерстной породы (14,78 и 11,81 \% соответственно). Но в мясе валушков бурятской грубошерстной породы отмечено более высокое содержание белка - 18,36 \%.

3.Установлено, что белок мяса валушков изученных пород содержит как заменимые, так и незаменимые аминокислоты, что делает мясо овец биологически полноценным продуктом. Полученные данные согласуются с исследованиями других авторов.

4.В мышечной ткани валушков бурятской грубошерстной и тувинской короткожирнохвостой содержание тяжелых металлов не превышает предельно допустимую норму. Можно сделать вывод, что мясо соответствует требованиям безопасного пищевого продукта.

5.При проведении органолептической оценки экспертной комиссией отдано предпочтение образцам бурятской грубошерстной породы по показателям качества мяса и бульона $(8,1$ и 8,05 баллов соответственно).

\section{Литература}

1. Бубнов Б.Б. Современное состояние и пути выхода из кризиса: доклад // Сайт Министерства сельского хозяйства и продовольствия Республики Бурятия. Овцеводство Бурятии. URL: http://www.fadr.msu.ru/rin/sheep/ bybnov.html.

2. Тайшин В.А., Лхасаранов Б.Б. Аборигенная бурятская овца. Улан-Удэ: БНЦ СО РАН, 1997. 123 c.

3. Шимит Л.Д., Двалишвили В.Г., Билтуев С.И. Мясная продуктивность тувинских овец в зависимости от зоны разведения // Вестник Тувинского государственного университета. 2016. № 2.

4. Методика оценки мясной продуктивности овец / Всерос. ин-т животноводства. Дубровицы, 1978. 45 с.

5. ГОСТ Р 51479-99 (ИСО 1442-97). Мясо и мясные продукты. Метод определения массовой доли влаги // Электронный фонд правовой и нормативно-технической документации. URL: http://docs.cntd.ru/document/ 1200028186.

6. ГОСТ 25011-2017. Мясо и мясные продукты. Методы определения белка // Электронный фонд правовой и нормативно-технической документации. URL: http://docs.cntd.ru/ document/1200146783.

7. ГОСТ 23042-2015. Мясо и мясные продукты. Методы определения жира // Электронный фонд правовой и нормативно-технической документации. URL: http://docs.cntd.ru/ document/1200133107.

8. ГОСТ 31727-2012 (ISO 936:1998). Мясо и мясные продукты. Метод определения массовой доли общей золы // Электронный фронд правовой и нормативно-технической документации. URL: http://docs.cntd.ru/document/ 1200098742.

9. Группа компании Люмекс. Капель - 105 М. Методическое обеспечение. URL: https:// www.lumex.ru/catalog/capel-105105m.php.

10. Ооржак А.Б. Продуктивные и некоторые биологические особенности тувинских короткожирнохвостых овец степного типа: автореф. дис. ... канд. с.-Х. наук. Улан-Удэ, 2011. $17 \mathrm{c}$.

11. Костриков М.А. Сравнительная характеристика продуктивных качеств бурятских полугрубошерстных и грубошерстных овец: автореф. дис. ... канд. с.-Х. наук. Улан-Удэ, $2007.17 \mathrm{c}$.

12. Монгуш Ж.Н. Продуктивные качества овец степного типа тувинской короткожирнохвостой породы в зависимости от их линейной принадлежности: автореф. дис. ... канд. с.-х. наук. Улан-Удэ, 2015. 17 с.

13. Никитенко B.E., Никитенко Д.В. Мясная продуктивность овец. М., 2009. С. 373-379.

14. Рядинская Н.И., Иконникова О.Л., Мезенцев С.В. Химический и аминокислотный состав мяса овец приактунского типа горноалтайской породы в раннем постнатальном онтогенезе // Вестник Алтайского государственного аграрного университета. 2012. № 10. C. 92-95.

15. Мамаев С.Ш., Кубатбеков Т.С., Галиева 3.А. Состав и качество мяса молодняка овец // Известия ОГАУ. 2014. № 2. С. 191-192.

16. Баранников В.Д., Кириллов Н.К. Экологическая безопасность сельскохозяйственной продукции. М.: КолосС, 2006. 352 с.

17. Жилякова Г.М., Лакгонова М.Д. содержание тяжелых металлов в баранине степной зоны Республики Бурятия // Овцы, козы, шерстяное дело. 2016. № 3. С. 44-46. 


\section{Literatura}

1. Bubnov B.B. Sovremennoe sostojanie i puti vyhoda iz krizisa: do-klad // Sajt Ministerstva sel'skogo hozjajstva i prodovol'stvija Respubliki Burjatija. Ovcevodstvo Burjatii. URL: http://www.fadr.msu.ru/rin/sheep/ bybnov.html.

2. Tajshin V.A., Lhasaranov B.B. Aborigennaja burjatskaja ovca. Ulan-Udje: BNC SO RAN, 1997. $123 \mathrm{~s}$.

3. Shimit L.D., Dvalishvili V.G., Biltuev S.I. Mjasnaja produktiv-nost' tuvinskih ovec $\mathrm{V}$ zavisimosti ot zony razvedenija // Vestnik Tuvinskogo gosudarstvennogo universiteta. 2016. № 2.

4. Metodika ocenki mjasnoj produktivnosti ovec / Vseros. in-t zhivotnovodstva. Dubrovicy, 1978. $45 \mathrm{~s}$.

5. GOST R 51479-99 (ISO 1442-97). Mjaso i mjasnye produkty. Metod opredelenija massovoj doli vlagi // Jelektronnyj fond pravovoj i normativno-tehnicheskoj dokumentacii. URL: http://docs.cntd.ru/document/ 1200028186.

6. GOST 25011-2017. Mjaso i mjasnye produkty. Metody opredelenija belka // Jelektronnyj fond pravovoj i normativno-tehnicheskoj dokumentacii. URL: http://docs.cntd.ru/document/ 1200146783.

7. GOST 23042-2015. Mjaso i mjasnye produkty. Metody opredelenija zhira // Jelektronnyj fond pravovoj i normativno-tehnicheskoj dokumentacii. URL: http://docs.cntd.ru/document/ 1200133107.

8. GOST 31727-2012 (ISO 936:1998). Mjaso i mjasnye produkty. Metod opredelenija massovoj doli obshhej zoly // Jelektronnyj fond pravovoj i normativno-tehnicheskoj dokumentacii. URL: http://docs.cntd.ru/document/ 1200098742.

9. Gruppa kompanii Ljumeks. Kapel' - 105 M. Metodicheskoe obespe-chenie. URL: https:// www.lumex.ru/catalog/capel-105105m.php.

10. Oorzhak A.B. Produktivnye i nekotorye biologicheskie osobennosti tuvinskih korotkozhirnohvostyh ovec stepnogo tipa: avtoref. dis. ... kand. s.-h. nauk. Ulan-Udje, 2011. 17 s.

11. Kostrikov M.A. Sravnitel'naja harakteristika produktivnyh kachestv burjatskih polugrubosherstnyh i grubosherstnyh ovec: avtoref. dis. ... kand. s.-h. nauk. Ulan-Udje, 2007. 17 s.

12. Mongush Zh.N. Produktivnye kachestva ovec stepnogo tipa tuvinskoj korotkozhirnohvostoj porody $v$ zavisimosti of in linejnoj prinadlezhnosti: avtoref. dis. ... kand. s.-h. nauk. UlanUdje, 2015. $17 \mathrm{~s}$.

13. Nikitenko V.E., Nikitenko D.V. Mjasnaja produktivnost' ovec. M., 2009. S. 373-379.

14. Rjadinskaja N.I., Ikonnikova O.L., Mezencev S.V. Himicheskij i aminokislotnyj sostav mjasa ovec priaktunskogo tipa gorno-altajskoj porody $v$ rannem postnatal'nom ontogeneze // Vestnik Altajskogo gosudar-stvennogo agrarnogo universiteta. 2012. № 10. S. 92-95.

15. Mamaev S.Sh., Kubatbekov T.S., Galieva Z.A. Sostav i kachestvo mja-sa molodnjaka ovec // Izvestija OGAU. 2014. № 2. S. 191-192.

16. Barannikov V.D., Kirillov N.K. Jekologiches kaja bezopasnost' sel'skohozjajstvennoj produkcii. M.: KolosS, 2006. $352 \mathrm{~s}$.

17. Zhiljakova G.M., Lakgonova M.D. soderzhanie tjazhelyh metallov $v$ baranine stepnoj zony Respubliki Burjatija // Ovcy, kozy, sherstjanoe delo. 2016. № 3. S. 44-46. 